\title{
Aligning Retail Reverse Logistics Practice with Circular Economy Values: An Exploratory Framework
}

\begin{abstract}
Although there is a growing body of literature concerning Circular Economy (CE), there is little, in terms of frameworks in the literature, which focuses on embedding $\mathrm{CE}$ values in consumer Retail Reverse Logistics (RRL) operations. The aim of this paper is to present a conceptual framework that supports the adoption of CE values within RRL operations. The framework is designed to assist both practitioners and academics in better understanding the key management aspects involved. The methodology adopts a mixed methods approach combining a desk-based research with rich empirical data from interviews with senior management practitioners and academics in the fields of CE and RRL. From this research, it was found that embedding CE values within RRL necessitates the adoption of a multi-faceted approach. The adoption of the framework will have an impact on practitioners by assisting them in moving towards a more restorative and less impactful approach to their RRL practices. The work is considered innovative and novel as this is the first time the empirical results that suggest a multi-dimensional approach embedding CE values in RRL operations are presented.

Keywords: Circular Economy; Reverse Logistics; Retail; Returns Management; Supply Chain Management
\end{abstract}

Published by Taylor and Francis. This is the Author Accepted Manuscript issued with: Creative Commons Attribution Non-Commercial License (CC:BY:NC 4.0).

The final published version (version of record) is available online at DOI:10.1080/09537287.2018.1449266.

Please refer to any applicable publisher terms of use. 


\section{INTRODUCTION}

There seems to be a direction in society that the current model in the industrial economy is characterised by 'take, make, dispose', where raw materials are extracted, converted into products, sold and used by end users, and after their end-of-life, the products are being disposed of. Although some high value items are recycled, in reality much still ends up in landfill. There is an increasing view that this is an unsustainable way forward, especially in the midst of the emerging global economy and growing middle class. There has been ongoing discussion at the senior level in commercial organisations, by politicians, non-governmental organisations and academics, about the concept of Circular Economy (CE), where products are being reused to maximise the circulation between the points of use and production.

The term CE is described by the Ellen MacArthur Foundation (EMF) as an industrial economy that is restorative and regenerative, aimed at keeping products, components and materials at their highest utility and value at all times. Unlike the linear economy model of 'take, make, dispose', CE aims to minimise the consumption of finite resources and raw materials in the manufacture of products. CE can be seen as an effort to foster sustainability and environmental protection, but the main difference between $\mathrm{CE}$ and sustainability is that $\mathrm{CE}$ puts emphasis on the maximum circulation of the content of end-of-life products, back to the point of production and use, in addition to reducing the environmental impact. Both technical and biological materials from end-of-life products will be properly treated, so that if inevitable, these materials can safely be released into the biosphere. The ultimate goal of $\mathrm{CE}$ is therefore twofold: maximising the recirculation and minimising the contents that could end up in landfill or incineration.

As an industrial system, CE supports a restorative concept through the intelligent design of materials, products and systems, and the business model. Preston (2012) interpreted it as the redesign of global production and consumption systems, which combines environmental, resources, technology and consumer demand. CE strives for maximisation of the 'design for reuse' thus aiming to retain the intrinsic value of the materials being recirculated through innovations across the various fields (Lacy and Rutqvist, 2015; Webster, 2015). As part of that endeavour, reverse logistics clearly fits with, and thus becomes the major component in, CE. Activities within the reverse logistics within the context of $\mathrm{CE}$ would therefore encompass the management of product returns followed by end-of-life processing and product recovery activities such as repair, reuse, refurbish, remanufacture and recycle. 
Reverse logistics has become a key concern in business as it has a direct impact on the bottom line (Stock, 1998; Mason, 2002), especially when returns management is an integral element. Recent return figures indicated a staggering $£ 5.75$ bn within the UK retail sector (Bernon and Cullen, 2007), representing 5-20\% (Daugherty et al., 2001), up to around 50\% in some sectors (Rogers et al., 2002; Prahinski and Kocabasoglu, 2006) in return rates. The rise of Internet and home shopping, combined with the more liberal returns policies, exacerbated by shortened product life cycles, are a number of factors that have contributed to this phenomenon (Bernon and Cullen, 2007). The costs of dealing with product returns in reverse logistics are often incomparable to those of forward logistics as, typically, supply chains are optimised around forward logistics (Lambert and Stock, 1987).

Despite the growing interest in academic literature in reverse logistics over the past 15 years, the research focus has typically been on minimising the return levels experienced by avoidance techniques (Bernon et al., 2011), and mitigating operating costs and increasing the recovery values of returned products (Bernon et al., 2016). Whilst a number of papers have considered the sustainability and environmental issues of reverse logistics, there is little discourse evaluating the managerial implications from adopting a more CE-based view.

The macro-economic benefits of adopting a CE approach have been recognised by a number of organisations. The EMF (2013) suggests that over US\$1 trillion a year could be generated by 2025 for the global economy and 100,000 new jobs created during the next five years if companies focus on encouraging the build-up of circular supply chains to increase the rate of recycling, reuse and remanufacture, which are all integral parts of a reverse logistics system. In their strategy document, Closing the loop - An EU action plan for the CE, the European Union (EU) (2015) stipulates its vision for transitioning to a $\mathrm{CE}$ and highlights a range of benefits including, protecting businesses against scarcity of resources, volatile prices, creating new business opportunities, improving innovation, production efficiency and conserving energy.

While these benefits have been identified, fundamental changes throughout the value chain are required to implement a CE (European Environment Agency, 2016). This has to start from product design and production process, to product usage and reverse logistics processes (reuse, remanufacturing, recycling, etc.). However, considerable challenges exist between our conventional linear systems and models of circularity. The intention of our work is to present a framework that will support companies' transition from their existing processes. Our work 
also identifies important areas for further research that will enrich our understanding of the enabling factors.

The overarching aim of the work described in this paper is to better understand the ways in which the practice of Retail Reverse Logistics (RRL) engages with CE. RRL describes the activity of returning goods back through the supply chain with a focus on retailers. This can originate from a customer returning a product to a retail outlet or a commercial decision to withdraw the product from sale (Bernon et al., 2011). Further, with the emergence of on-line retailing, this definition can be extended to include customers returning products via multiple reverse channels, for example, postal service, drop-off points and parcel carriers. In our experience, whilst there is an increasing awareness of the need for a CE approach, many companies have little appreciation of how the values of CE can be utilised or embedded in their practices. The gap that this paper seeks to address is the lack of a holistic framework for embedding these values in RRL operations. The focal point of this research is the retailer and management of its supply chain.

Whilst CE takes a systems approach from design through to recycle, we are mindful that reverse logistics management is a key component within this spectrum. We have therefore started by introducing some key concepts in $\mathrm{CE}$, and in the subsequent sections we will explore key and relevant topics in reverse logistics and CE through a brief literature review. This will mainly cover the fundamental principles of CE, current work in reverse logistics design, characteristics, and more importantly, areas where CE and RRL do blend, yet lack empirical research and practical implications. This is followed by a description of the methodology used to build the framework before presenting the findings from a synthesis of the empirical results and literature. Finally, the implications for practice are discussed along with areas for future research.

\section{REVERSE LOGISTICS AND CIRCULAR ECONOMY}

Understanding the difference between forward and reverse logistics is crucial in the management of reverse logistics systems. Tibben-Lembke and Rogers (2002) highlighted a number of key factors that cause the differences, for instance, the ability to forecast volumes, transport systems being 'many-to-one' rather than 'one-to-many', product quality not uniform, unclear disposition routes, costs not directly visible and speed not considered a priority. This suggests other aspects affecting reverse logistics (including managerial, finance and alignment 
with the strategic direction of the business) that are not the same as for forward logistics or typical outbound operations.

The scope and initial definitions of reverse logistics are somewhat limited to the movement of materials and products in the opposite direction to the main flow (Murphy, 1986; Lambert and Stock, 1987; Murphy and Poist, 1989), i.e. from supplier to factory, from factory to distribution channels, or from retailers to customers. In the 1990s, a number of new definitions of reverse logistics emerged, especially those that are not only describing the reverse flow, but emphasising the activities within the flow, such as recycling, reusing, disposing, etc. (Stock, 1992; Kopicki et al., 1993; Stock, 1998; Carter and Ellram, 1998). As time moved on, more formal and sophisticated definitions of reverse logistics began to develop. Rogers and TibbenLembke (1999), for example, adopted the definition of logistics given by the Council of Logistics Management, to define reverse logistics as "the process of planning, implementing, and controlling the efficient, cost-effective flow of raw materials, in-process inventory, finished goods, and related information from the point of consumption to the point of origin for the purpose of recapturing value or proper disposal". Reverse logistics is viewed as the management action of logistics functions (Kopicki et al., 1993; Rogers and Tibben-Lembke, 1999; Stock, 1998; Govindan et al., 2012), recovery/reuse activities (Stock, 1992; Kopicki et al., 1993; Carter and Ellram, 1998; Ravi and Shankar, 2005), distribution channel (Murphy, 1986; Murphy and Poist, 1989; Horvath et al., 2005), recapturing values (Rogers and TibbenLembke, 1999, 2001), reverse flow (Murphy, 1986; Lambert and Stock, 1987; Murphy and Poist, 1989; Lu and Bostel, 2007; Du and Evans, 2008), and cost (Rogers and Tibben-Lembke, 1999; Meade and Sarkis, 2002; Daugherty et al., 2005; Lambert et al., 2011).

One of the most critical aspects within reverse logistics is product return that may include: return of defective products along with product recalls, return for maintenance, repair and overhaul of products, and return of excess products. More recently, manufacturers and retailers in certain markets are legally obliged to take back and recycle their products at the end-of-life (Walther and Spengler, 2005). In the context of reverse logistics definition, however, product return is the beginning (starting point) of product recovery to recapture the remaining values of the (typically) end-of-life products (Blackburn et al., 2004). According to Thierry et al. (1995) and Srivastava (2008), there are a number of important activities within reverse logistics that typically incorporate direct reuse (direct resale), product recovery 
management (test/inspection, disassembly, service, repair, refurbish, remanufacture, cannibalisation, recycle) and waste management (disposal, landfill, incineration).

The EMF often uses Figure 1 to elaborate the two routes of circulation of materials from the point of use to the point of production. At the spine of the "butterfly" diagram lies the outbound processes (i.e. forward logistics) and each side of the spine can be considered as the opposite route (reverse logistics) of what the EMF terms as technical and biological materials. It is clear that reverse logistics fits with CE, especially the reverse route of the technical materials, which resembles the reverse logistics activities stated in much of the academic literature (Murphy, 1986; Lambert and Stock, 1987; Murphy and Poist, 1989; Stock, 1992; 1998; Kopicki et al., 1993; Carter and Ellram, 1998; Rogers and Tibben-Lembke, 1999).

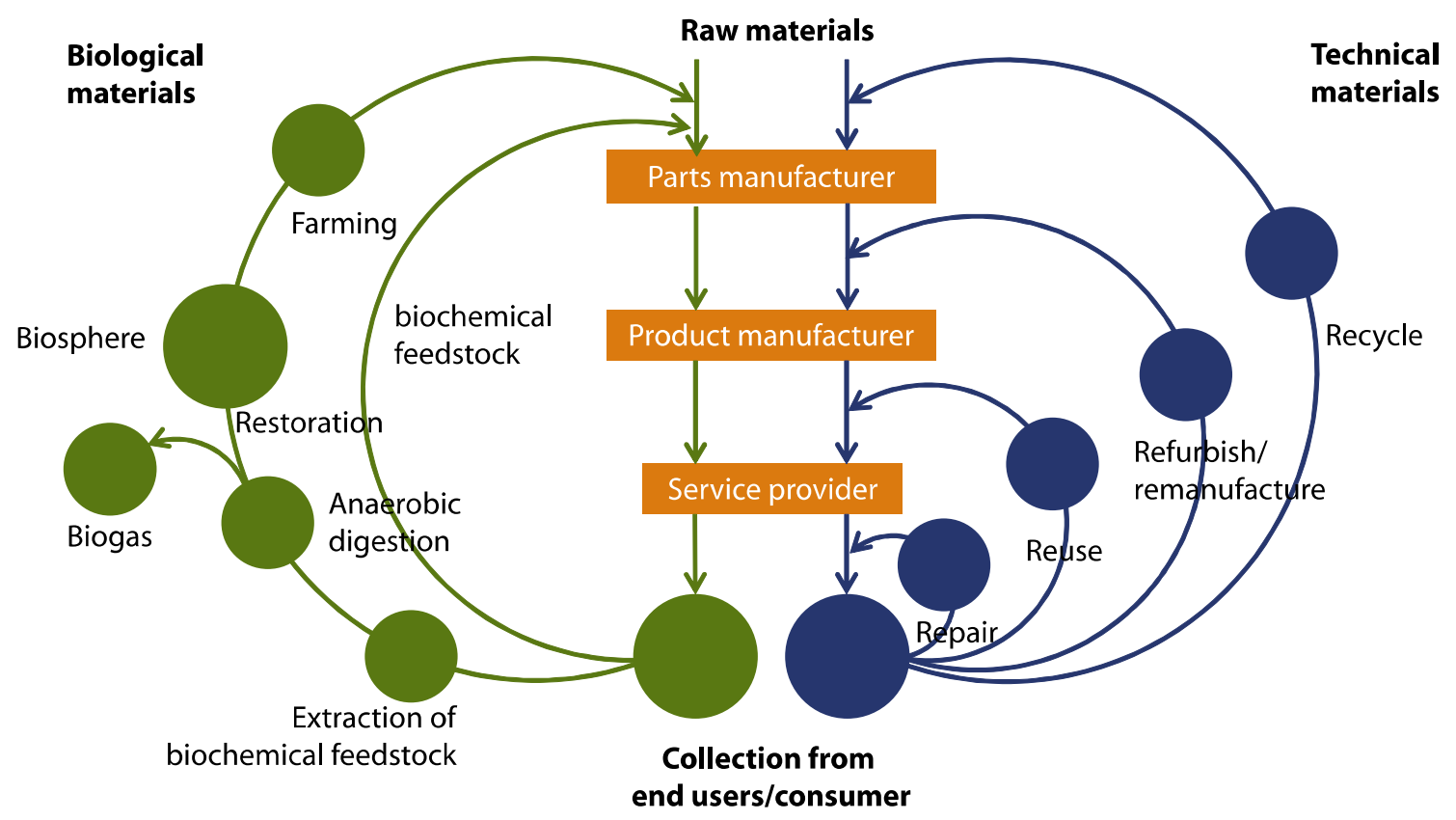

Figure 1 - Circular Economy (Adapted from EMF (2013))

To support the effective implementation of the CE concept, a number of guiding principles have been proposed by numerous researchers and organisations. Webster (2015) and Lacy and Rutqvist (2015), for instance, consider 'design for reuse' as a principle to retain the intrinsic value of the materials being recirculated. Preston (2012) concurred with that principle and further added 'intelligent design' of materials, products and systems, and the business model as another guiding principle that ensures the restorative concept in CE. The EMF in many of their reports proposes five principles of CE: 'design out waste', 'build resilience', 'work towards using energy from renewable sources', 'think in system' and 'think in cascades'. 
Whilst there is an increasing awareness and appreciation of CE, at the same time there seems to be little appreciation of how the principles and values of CE can be utilised/embedded in the practices of reverse logistics. This is exacerbated by the fact that literature describing formal representation, frameworks and methods for designing reverse logistics that take into account the $\mathrm{CE}$ values, appears to be lacking. Much of the academic work discussing the design of reverse logistics is typically focused on the design of the reverse logistics network (e.g. Fleischmann, 2001; Bostel et al., 2005; Salema et al., 2007; Mutha and Pokharel, 2009; Pishvaee et al., 2009). The gap that this paper seeks to address is therefore the lack of a holistic framework that supports the adoption of CE values, especially in RRL operations.

We therefore propose a conceptual framework that supports the adoption of CE values. We design the framework to assist both practitioners and academia in better understanding the key management aspects involved and the potential conflicts that may occur, e.g. commercial considerations and company business strategy that may not align well with $\mathrm{CE}$. The research objective, being the development of a conceptual framework, is addressed through the following research questions:

RQ1. What are the antecedents to enable CE values in RRL processes?

RQ2. How can organisations embed CE values in their RRL processes?

Our purpose in addressing these two exploratory questions is to develop a framework which offers practitioners a mechanism by which they can more successfully implement $\mathrm{CE}$ principles, while for our academic colleagues, suggests a broad agenda for further research.

\section{METHODOLOGY}

To develop the framework reported in this paper, a mixed methods approach has been adopted based on an inductive process in developing concepts and building a framework to explain or predict phenomena (Strauss and Corbin, 1998). The unit of analysis in our study is large-size retailers having more than 250 employees, in which we focus on their RRL operations. The unit of analysis was specified bearing in mind the research questions and the theoretical criteria (Eisenhardt, 1989). We expect retailers to have robust internal supply chains with a relatively high volume of product returns and be most likely to have considered CE practices.

Initially, a desk-based literature review was undertaken to identify the key dimensions in managing reverse logistics processes, and the key values and principles associated with the 
phenomenon of the CE. The literature review strategy was developed by first identifying the relevant databases, including journals, books and conference proceedings. The primary databases used were Scopus, Web of Knowledge, Thomson Reuters, ABI/Inform, Emerald and IEEE Xplore. Keywords such as 'reverse logistics', 'circular economy', 'product return', 'product recovery', 'retail', 'sustainability' and their combinations were applied to retrieve the papers. Having considered the entire search strings used, there were 3236 records retrieved, and by filtering, cross-checking and removing redundancy, the papers were reduced to 192. By reading the abstracts, the scope of each paper was checked and some papers were excluded, leaving 99 deemed relevant and suitable for review. These papers demonstrated their relevance to our research questions, in particular in identifying the key dimensions for managing reverse logistics processes, and the key values and principles associated with the phenomenon of the CE. From this first stage literature review, we also obtained other papers frequently cited by those papers we initially reviewed (e.g. Hooley et al., 1998; Du et al., 2007) that later on shaped our thoughts. The literature review outcomes formed the foundation of our framework.

Table 1 describes the interview data. In total, 21 interviews were conducted comprising 15 retailers (with return operations); three specialist returns management third party logistics (3PL) organisations; two academics (from two institutions; each of whose research experience of reverse logistics spanned more than 10 years) and one consultant (with industrial work experience in reverse logistics spanning more than 10 years). The retailers selected were well known UK brands with a significant market presence, but for commercial confidentiality reasons have been anonymised.

Table 1 - Company and interviewee data

\begin{tabular}{llll}
\hline Company & Business & Data type & Job title \\
\hline A & Retailer & RRL & Director of Retail Logistics \\
B & Retailer & RRL & Reverse Logistics Manager \\
C & Retailer & RRL & Senior Business Analyst \& Project Manager EMEIAR \& Oceania \\
D & 3PL & RRL & Solution Design Analyst, Consumer Logistics \\
E & Retailer & RRL & Returns Manager \\
F & Retailer & RRL & Head of Operational Excellence/Customer Returns \\
G & Retailer & RRL & Head of Returns and Operational Development/Stock Loss and \\
H & Retailer & RRL & Returns Process Manager \\
I & Retailer & RRL & Supply Chain Manager
\end{tabular}




\begin{tabular}{llll} 
J & Retailer & RRL & VP Supply Chain EMEA and APAC \\
K & Retailer & RRL & Logistics Director \\
L & 3PL & RRL & Returns Manager \\
M & 3PL & RRL & Head of e-commerce Development \\
N & Retailer & RRL \& CE & Head of General Merchandise Returns \\
O & Consultant & RRL \& CE & Consultant with reverse logistics expertise and operational experience \\
P & Retailer & RRL \& CE & Head of Logistics \\
Q & Retailer & CE & Returns Manager \\
R & Retailer & CE & Commercial Returns Manager \\
S & Academic & CE & Professor \\
T & Academic & CE & Principal Lecturer \\
U & Retailer & CE & Head of Quality \& Commercial Support \\
\hline
\end{tabular}

All the interviewees were supply chain professionals with knowledge of reverse logistics operations. They represented a range of retail sectors including, grocery, mobile phone, mass merchandise, car entertainment and accessories. To maintain confidentiality, the names of individuals have also been omitted.

We adopted purposive sampling, i.e. a small number of people "nested in their context and studied in-depth", and "not wholly pre-specified but can evolve" (Miles et al., 2014). They were selected not only for their expertise and commercial experience, but also their willingness to invest their time in this research. The academics whose research area incorporated CE were also consulted, especially when developing the initial framework, with the aim that the framework is not only practically feasible but also academically rigorous.

Selection of the interviewees was also based on the interviewees' perceived ability to consider the implications of $\mathrm{CE}$ values within the domain of reverse logistics. While a detailed knowledge of CE values was not a prerequisite, a comprehension of basic understanding was deemed important. Interviewees were drawn from two main sources, either members of the Chartered Institute of Logistics and Transport UK (CILT UK) Reverse Logistics Forum or those known to the research team through previous return management research (Bernon et al., 2013).

To pre-qualify the suitability of prospective interviewees, each was sent an email which outlined the research aim and type of data we were seeking from them. We also attached the interview protocol consisting of some high level questions, from which we should be able to 
gauge their knowledge of reverse logistics and some working understanding of $\mathrm{CE}$, and a graphical representation of the initial framework. Furthermore, during the interview process, it would have been clear to us if the interviewees were not able to comment on CE and we would have discounted them at that point.

We adopted a semi-structured interview approach. Each interview lasted typically one hour, and at least two interviewers (researchers) were present to help improve consistency of the questioning/probing. The interview questions were deliberately designed to allow the researchers to flexibly probe the interviewees as the interview process continued. The interview protocol had been piloted with a doctoral student and an academic who have extensive knowledge in reverse logistics and CE. To gather data, each element of the framework was described and interviewees were prompted to give their views. A number of themes were used consistently to explore the two research questions. All interviews were recorded and transcribed for the purpose of thematic analysis.

Textbooks in qualitative research largely expose bias from the points of view of the researcher (Miles et al., 2014). However, we also recognise that bias could arise from the interviewees, especially from their association with the organisations they work for and/or from their personal opinion. The former was reduced by constantly reminding them what we wanted to achieve, i.e. the context of our research questions, rather than company-specific contexts. As we wanted to obtain their wealth of experience, we deliberately allowed personal bias to emerge. In fact, their perceptions about the research phenomena we posed to them are valuable contributions, grounded in the world of practice. It is the role of the interviewers involved to moderate this effect. We triangulated our data by the use of multiple interviewers, as suggested by Dubé and Paré (2003) and McCutcheon and Meredith (1993). This would increase our confidence in handling the complexity and richness of the interview data (Eisenhardt, 1989).

To explore RQ1: What are the antecedents to enable CE values in RRL processes?, interviewees were prompted to consider 'barriers' or 'facilitators' they felt were important in the successful adoption of CE principles within reverse logistics processes. Prompts were also made to consider the antecedents within the function of reverse logistics, and inter- and intraorganisational dimensions.

To explore RQ2: How can organisations embed CE values in their RRL processes?, the interviewer utilised a step-wise process to present the 'embedding the CE values in the RRL 
processes' element of the framework and described the process for 'mapping and interpretation'. Interviewees were asked at each stage to offer their expert views on the approach and to respond based on the following criteria: usability, applicability, consistency and repeatability, and utility.

We manually analysed the interview transcripts and aggregated the interview data into a number of themes (Creswell, 2013). Although time-consuming, it allowed the emerging themes to be discussed more thoroughly amongst the three researchers, and subsequently reduced misinterpretation (researcher's bias) had it been done individually by the researchers. For each interview script, the passages were marked and highlighted, and the resultant themes were then discussed in order to arrive at an agreement. Indeed, there were occasions when the researchers had different interpretations of certain themes. In this circumstance, the passages from where the particular theme was extracted were jointly re-read and discussed by the three researchers (Barratt et al., 2011), before the final theme was finally agreed.

\section{DEVELOPING THE CONCEPTUAL FRAMEWORK}

Although the body of literature to a large extent covered the various topics in RRL and CE, we found little contribution towards a more holistic view on how to integrate them. We therefore posit that a framework (see Figure 2) is needed to encapsulate the relevant elements of RRL and $\mathrm{CE}$, and this would be the main contribution of this paper.

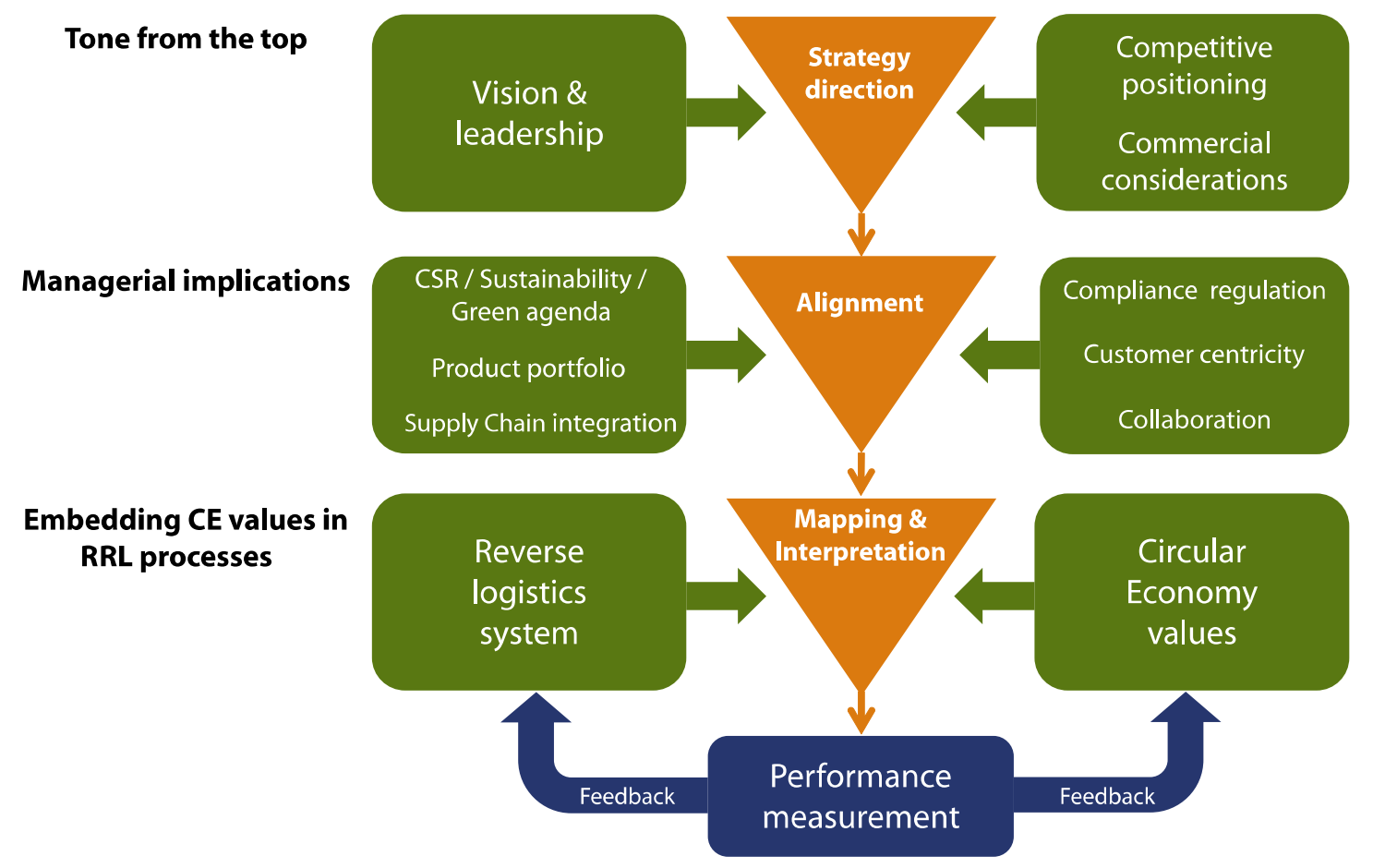


Figure 2 - The framework for aligning Circular Economy and Retail Reverse Logistics

The framework takes a cascade or waterfall approach and consists of three key aspects:

1. 'Tone from the top'

2. Managerial implications

3. Embedding CE values in RRL processes

\section{1 'Tone from the top'}

'Tone from the top' is concerned with ensuring that any initiatives to move towards CE and reverse logistics processes are in line with the overall vision and leadership direction of the business and have a good fit with the competitive positioning of the organisation. The alignment would drive the strategic direction of the business and subsequently guide the operationalisation and implementation of CE and RRL.

\section{a. Vision and leadership}

The role of vision and leadership in driving change is a recurring theme within the management literature. Examples of the importance of vision in leadership have also been documented in driving forward sustainability strategies. In the UK, the Marks and Spencer Plan A strategy has been attributed to the then CEO Stuart Rose (Grayson, 2011) and similarly, Lee Scott, the past CEO of Walmart was seen as instrumental in leading their Sustainability 360 programme (Veleva, 2008) while also influencing many industry leaders (Malhotra et al., 2013). Within the domain of CE, a number of examples exist, notably, Desso ${ }^{1}, \operatorname{Ricoh}^{2}$ and Philips ${ }^{3}$ who have implemented CE initiatives, providing evidence where the vision has come from senior

\footnotetext{
${ }^{1}$ In 2008, inspired by the Cradle to Cradle ${ }^{\circledR}$ concept, the top team at Desso including the CEO Alexander Collot d'Escury initiated a circular concept for the recovery of their commercial carpet tile business (see http://www.desso.com/c2c-corporate-responsibility/circular-economy/ accessed 3 Feb 2017)

${ }^{2}$ Ricoh have a long established heritage in managing their photocopiers in a circular way which is central to their business model, and developed their Comet Circle Model in 1994 (see https://www.ricoh.com/environment/management/concept.html accessed 3 Feb 2017)

${ }^{3}$ Philips have implemented a number of CE initiatives (see http://www.philips.com/aw/about/sustainability/sustainable-planet/circular-economy.html accessed 3 Feb 2017) supported by CEO Frans van Houten who has stated that "for a sustainable world, the transition from a linear to a circular economy is essential".
} 
management commitment and has been a driving force for change. We therefore posit that senior management commitment, vision and leadership would be an important antecedent.

\section{b. Competitive positioning}

The second antecedent is an understanding of the competitive position of the business. We consider competitive positioning as a way to distinguish the offering and value proposition by establishing a position in the competitive landscape. There are two schools of thought describing competitive position: one based on internal, organisational resources and capabilities (resource-based view) and one that emphasises external market orientation. Both paradigms seek to find a match between market requirements and company abilities to serve them (Hooley et al., 1998).

We include this antecedent because the commercial considerations may not always align themselves well to CE. However, competitive positioning, according to Du et al. (2007), plays a critical role in gaining relational rewards from the customers. Furthermore, Winkler (2011) contended that competitive positioning works hand-in-hand with the shift from linear economy to $\mathrm{CE}$. The general assumption is that if a product is kept at the highest level of utilisation, then theoretically there is more value in a commercial sense and thus it might align with CE. Having a clear competitive positioning will help companies appreciate the commercial implications related to their commitment to $\mathrm{CE}$ and how this will impact on the commercial structure. Similarly, understanding the commerciality and what the commercial value means to CE is also a crucial antecedent.

\subsection{Managerial implications}

Managerial implications here emphasise the alignment between the RRL/CE and other managerial facets, for instance sustainability, product portfolio, supply chain integration, compliance with regulations, customer-centricity and collaboration.

\section{a. Alignment between RRL/CE and Corporate Social Responsibility (CSR), Sustainability and Green Agenda}

The concepts of sustainability and sustainable development have been gaining increased attention over the past three decades. The most widely cited definition of sustainable development originates from the UN-sponsored World Commission on Environment and Development, commonly known as the Brundtland Report, which states that 'sustainable development is development that meets the needs of the present without compromising the 
ability of future generations to meet their own needs' (WCED, 1987). The essence of sustainability is recognition of the need to balance economic development with the environmental impacts and social injustice - often referred to as the 'triple bottom line' (Elkington, 1997).

While sustainability and CE share a number of overarching principles, their focus differs in that the $\mathrm{CE}$ discourse has its origins in industrial ecology. A key principle of $\mathrm{CE}$, for instance, is to design products so that there is equilibrium between ecological systems and economic growth. Therefore, $\mathrm{CE}$ is not just concerned with the reduction of the use of the environment as a sink for residuals but rather with the creation of self-sustaining production systems in which materials are used over and over again (Genovese et al., 2017). Moreover, CE is primarily concerned with maintaining the highest utility of products (EMF, 2013), cascading (EMF, 2013), leakage and energy consumption and reusable energy (EMF, 2015), whereas sustainability programmes span a much broader spectrum of economic, social and environmental measures (GRI, 2015).

As many organisations will typically already have well established CSR/sustainability/green agenda, it will be important that any new CE initiative is well aligned with these existing programmes. Thus, by aligning RRL/CE to sustainability, we aim to understand how CE fits in with the existing sustainability/green agenda within a company.

\section{b. Alignment between RRL/CE and Product Portfolio}

The alignment between RRL/CE and product portfolio is critical as the way in which products can be recirculated, e.g. via remanufacturing, depends largely on the product structure, material contents and production/manufacturing methods (Sundin and Bras, 2005; Meier et al., 2010). If we are embarking on RRL/CE, the key question we might want to ask ourselves is, Does our existing product portfolio lend itself to RRL/CE? There are many examples where recirculation is feasible, where there are secondary markets (Park et al., 2010; Dhakal et al., 2016). For instance, photocopiers and mobile phones lend themselves to product recirculation as they contain many high value density products. Both can be repaired/refurbished and immediately sold as second-hand products and there is a market for them (Neto et al., 2016).

There are, however, products that do not lend themselves to RRL/CE: low value products or products with short life cycles whose complexity of disassembly or repair processes is expensive and could result in repairing/refurbishing them being beyond their economic value, 
similarly with products that are bulky and difficult to move/transport without specialist material handling tools. Reselling low value density products could not extend their life, so the RRL/CE would not be feasible. Thus we need to consider the product portfolio right from the beginning of planning the RRL/CE and carefully select the portfolio of products that is relevant, thus feasible.

\section{c. Alignment between RRL/CE and Supply Chain Integration}

Generally, the supply chain literature addresses two key dimensions of integration: internal and external. Internal integration considers the nature of relationships between various functions within an organisation that work more collaboratively as a single entity, while external integration refers to the integration between a focal company, e.g. a manufacturer, and its external environment, e.g. suppliers and/or buyers (Bernon et al., 2013). Flynn et al. (2010: 59), define supply chain integration as "the degree to which a manufacturer strategically collaborates with its supply chain partners and collaboratively manages intra- and interorganisational processes".

With regard to intra-firm integration, we see a number of areas where the success of embedding CE within RRL processes will be dependent upon the level of integration with other functional areas. As an example, we would anticipate that a Design function would have a significant effect on the ability of products to be repurposed. Hence an integrated design strategy might include considerations for how products could be disassembled easily/quickly, preferably with little or no human/labour involvement. Further, we might see a shift from selling products to leasing them so that the Reverse Logistics function retains ownership and the ability to retrieve products. This would need an integrated strategy between both the Sales and Marketing functions.

With regard to inter-firm integration, we see opportunities to integrate with new organisations offering services linked to CE principles. This might include capabilities for repurposing products or access to new markets. Further, taking a more integrated approach may require adopting new relational forms (see f. below).

\section{d. Alignment between RRL/CE and Compliance Regulation}

Increasingly, legislators are implementing policies designed to increase levels of recycling and reduce the amount of waste going to landfill. In Europe, for example, the EU has introduced a raft of such legislation under the 'Producer pays' principle (Ameli et al., 2016) which places 
an obligation on manufacturers to take back and recycle products at their end-of-life. This includes EU Directive 2000/53/EC for end-of-life vehicles, which legislates that cars are manufactured in accordance with being reusable and/or recyclable to a minimum of $85 \%$ by mass and are reusable and/or recoverable to a minimum of $95 \%$ by mass, and EU Directive 2012/19/EU Waste of Electrical and Electronic Equipment (WEEE), which sets collection, recycling and recovery targets for all types of electrical and electronic equipment, along with the obligations placed upon manufacturers.

More recently, the EU has published a Communication document entitled 'Closing the loop An EU action plan for the Circular Economy' in which it has begun to adopt the language and principles of the CE (European Commission, 2015). Within this, it has published a proposal for a Directive amending the existing Directive 1999/31/EC on the landfill of waste. The proposal presents a new and 'ambitious circular economy package' (European Commission, 2016) with stringent new EU recycling targets as part of its ongoing Waste Target Review, including a ban on burying recyclable waste in landfill. If these Directives are transposed into law by Member States they will potentially have significant implications for organisations in terms of the reverse logistics systems so that they comply with the regulations.

It is evident that in the future, companies must consider ever-increasing and more stringent regulation of their business (Yuan et al., 2006) and must consider this as a driver for change (Smith and Crotty, 2008) by adopting CE values in reverse logistics processes.

\section{e. Alignment between RRL/CE and Customer-Centricity}

This alignment comes from the need to position customers at the centre of everything we do. The argument is that unless we have a customer who wants the product and is willing to accept a second-hand product, the products will not have market acceptability. Taking the example of a toaster - if it breaks down is there a way of fixing it; the question would be: Do we want to fix it or shall we buy a new one? Research in user-centred design has traditionally taken into account the involvement of the potential users because ultimately, product needs to be used and users need to be informed. Refurbished products, though in good working order, still look 'shabby', and thus we need to ensure their acceptability. Clearly, there is a customer-centricity element in this in terms of level of acceptability.

Customer values have to be considered in the framework as they affect the purchasing decision. The customer experience and centricity should therefore be built around a concept that is 
consumer-friendly. However, even where customers are willing to accept repaired or refurbished products, further evaluation would need to be made with regard to $\mathrm{CE}$ values to ensure the products fall within relevant prevailing legislation while also ensuring the benefits of repair/refurbishment are fully justified. For example, the trade-off between the energy use of a repaired product versus a new, more eco-efficient product.

\section{f. Alignment between RRL/CE and Collaboration}

Collaboration is not new to the supply chain. What is new, however, is that companies need to collaborate with others because they typically do not have the capability to implement the $\mathrm{RRL} / \mathrm{CE}$ to its full extent. "The lesson learned from successful experiences is that the transition towards $\mathrm{CE}$ comes from the involvement of all actors of the society and their capacity to link and create suitable collaboration and exchange patterns" (Ghisellini et al., 2016: 11). This can be done by designing the supply chain with collaboration in mind, involving third party companies who not only can take end-of-life products away from the point of usage and then recycle them, but more importantly, companies who can actually carry out higher level, more adding value (retaining) activities, i.e. refurbishment or remanufacture operations.

We therefore posit that organisations are unlikely to transition to a $\mathrm{CE}$ model without collaborating with other entities. These collaborative arrangements may take different forms ranging from multi-stakeholder groups collaborating to share good practice, e.g. the EMF CE100 group of companies, who collaborate on ways to scale up CE adoption (EMF, 2015) to complex systems of industrial symbiosis, "industries that traditionally work as separate entities become engaged in complex interplays of resource exchange... with the purpose of achieving economic and environmental benefits" (Ghisellini et al., 2016: 20).

\subsection{Embedding CE values in RRL processes}

The term 'principles of CE' has been mentioned and proposed in a number of ways by different publications related to CE (e.g. Pintér, 2006; Yuan et al., 2006; Yong, 2007; Geng et al., 2012; EMF, 2013; Stahel, 2013; Pan et al., 2015). Having expanded the depth and breadth of our literature analysis, however, we posit that those principles have not yet been elaborated in such a way that they can be readily used in the operationalisation of reverse logistics in particular.

We hereby provide a new collection of tenets that we term CE values, grouped into three categories: principles, intrinsic attributes and enablers (Ripanti, 2017). We term principles as the essential activities or guiding rules to be followed to implement $\mathrm{CE}$; intrinsic attributes as 
the natural characteristics belonging to that value; and enablers as external entities that will support the practicality, possibility and continuity of the CE implementation.

Table 2 lists the $15 \mathrm{CE}$ values we propose and their descriptions. These values are arguably the most critical aspects of CE that are aligned to RRL (Ripanti, 2017) but may be expanded in the future. The order is not important; what is more important is that the values serve three purposes: principles, intrinsic attributes and enablers, and can be used to support the implementation of CE-based RRL. Practically, these values will be made available to the designers of RRL operations and be embedded into the design process.

Table 2 - Circular Economy Values (Ripanti, 2017)

\begin{tabular}{|c|c|c|c|}
\hline & Value & Description & Derived from \\
\hline $\begin{array}{l}\text { Principle } \\
1\end{array}$ & $\begin{array}{l}\text { Cascades } \\
\text { orientation }\end{array}$ & $\begin{array}{l}\text { Aims to keep the materials, be they products, } \\
\text { components or materials or biological nutrients, } \\
\text { longer in circulation and for them to be } \\
\text { transformed into different types of products or } \\
\text { materials. }\end{array}$ & $\begin{array}{l}\text { IMSA (2013); EMF } \\
(2015) ; \text { Lacy and } \\
\text { Rutqvist (2015); Webster } \\
(2015)\end{array}$ \\
\hline $\begin{array}{l}\text { Principle } \\
2\end{array}$ & $\begin{array}{l}\text { Waste } \\
\text { elimination }\end{array}$ & $\begin{array}{l}\text { Emphasises that waste must be eliminated from } \\
\text { the very beginning of the product design, and } \\
\text { systematically considers, at subsequent circulation } \\
\text { stages, how waste can be further reduced and } \\
\text { eliminated. }\end{array}$ & $\begin{array}{l}\text { Geng et al. (2009); } \\
\text { Mathews and Tan (2011) }\end{array}$ \\
\hline $\begin{array}{l}\text { Principle } \\
3\end{array}$ & $\begin{array}{l}\text { Economic } \\
\text { optimisation }\end{array}$ & $\begin{array}{l}\text { Aims to achieve the production and consumption, } \\
\text { service and supply of money, so that a resilient } \\
\text { economy can be created, e.g. by improving } \\
\text { material productivity, enhancing innovation } \\
\text { capabilities, or shifting from mass production to } \\
\text { skilled labour. }\end{array}$ & $\begin{array}{l}\text { Pintér (2006);Yong } \\
\text { (2007); Ma et al. (2015) }\end{array}$ \\
\hline $\begin{array}{l}\text { Principle } \\
4\end{array}$ & $\begin{array}{l}\text { Maximisation } \\
\text { of retained } \\
\text { value }\end{array}$ & $\begin{array}{l}\text { Aims to retain products or components that over } \\
\text { time decline in value, by creating a suitable } \\
\text { treatment system so that the values can be } \\
\text { prolonged. }\end{array}$ & $\begin{array}{l}\text { Yuan et al. (2006); } \\
\text { Huamao and Fengqi } \\
\text { (2007); Dajian (2008); } \\
\text { Mathews and Tan (2011) }\end{array}$ \\
\hline $\begin{array}{l}\text { Principle } \\
5\end{array}$ & $\begin{array}{l}\text { Environmenta } \\
1 \\
\text { consciousness }\end{array}$ & $\begin{array}{l}\text { Promotes the preservation of environmental } \\
\text { resources and reduction of environmental impacts } \\
\text { by adhering to environmental regulations. }\end{array}$ & $\begin{array}{l}\text { Hongchun (2006); Zhu et } \\
\text { al. (2010); Pinjing et al. } \\
\text { (2013); Su et al. (2013) }\end{array}$ \\
\hline $\begin{array}{l}\text { Principle } \\
6\end{array}$ & $\begin{array}{l}\text { Leakage } \\
\text { minimisation }\end{array}$ & $\begin{array}{l}\text { Upholds the avoidance of loss of opportunities to } \\
\text { maximise the cascaded usage period of (a) } \\
\text { biological materials and the inability to } \\
\text { incorporate the nutrient back into the biosphere } \\
\text { due to contamination, and (b) technical materials } \\
\text { that are lost due to loss of materials, energy, }\end{array}$ & EMF $(2013,2015)$ \\
\hline
\end{tabular}




\begin{tabular}{|c|c|c|c|}
\hline & & $\begin{array}{l}\text { components and materials are not (or cannot be) } \\
\text { recovered. }\end{array}$ & \\
\hline $\begin{array}{l}\text { Attribute } \\
1\end{array}$ & $\begin{array}{l}\text { Systems } \\
\text { thinking }\end{array}$ & $\begin{array}{l}\text { Suggests that CE has to be looked at holistically, } \\
\text { and considers all of the elements/components in } \\
\text { the CE as a system that integrates and influences } \\
\text { one with another. }\end{array}$ & $\begin{array}{l}\text { Chen (2009); Li et al. } \\
\text { (2009); EMF (2013) }\end{array}$ \\
\hline $\begin{array}{l}\text { Attribute } \\
2\end{array}$ & Circularity & $\begin{array}{l}\text { Advocates building a circular process to preserve } \\
\text { the value of product or component or material by } \\
\text { keeping it in use longer through, e.g. repair, reuse, } \\
\text { remanufacture and recycle. }\end{array}$ & $\begin{array}{l}\text { Pintér (2006); Yong } \\
\text { (2007); Chen (2009); } \\
\text { Mathews and Tan } \\
\text { (2011); Yang (2011); } \\
\text { EMF (2015); Lacy and } \\
\text { Rutqvist (2015); UNEP } \\
\text { (2015); Webster (2015) }\end{array}$ \\
\hline $\begin{array}{l}\text { Attribute } \\
3\end{array}$ & $\begin{array}{l}\text { Built-in } \\
\text { resilience }\end{array}$ & $\begin{array}{l}\text { Is related to the internal capacity, robustness and } \\
\text { responsiveness of a CE system to recover quickly } \\
\text { from various disturbances, e.g. economy, } \\
\text { technology, etc. }\end{array}$ & EMF $(2013,2015)$ \\
\hline $\begin{array}{l}\text { Attribute } \\
4\end{array}$ & $\begin{array}{l}\text { Collaborative } \\
\text { network }\end{array}$ & $\begin{array}{l}\text { Is needed for the creation of materials' standards } \\
\text { and information flow in the circularity, and allows } \\
\text { stakeholders to work together within an industry } \\
\text { sector or between different industries to achieve } \\
\text { common goals. }\end{array}$ & $\begin{array}{l}\text { Geng and Doberstein } \\
\text { (2008); Hu et al. (2011); } \\
\text { Preston (2012) }\end{array}$ \\
\hline $\begin{array}{l}\text { Attribute } \\
5\end{array}$ & $\begin{array}{l}\text { Shift to } \\
\text { renewable } \\
\text { energy }\end{array}$ & $\begin{array}{l}\text { Highlights the ability of CE to reduce the energy } \\
\text { usage per unit of output and accelerates the shift } \\
\text { to renewable energy by design, treating the } \\
\text { economy as a valuable resource. }\end{array}$ & $\begin{array}{l}\text { Pinjing et al. (2013); Ma } \\
\text { et al. (2015); Pan et al. } \\
\text { (2015) }\end{array}$ \\
\hline $\begin{array}{l}\text { Attribute } \\
6\end{array}$ & $\begin{array}{l}\text { Optimisation } \\
\text { of change }\end{array}$ & $\begin{array}{l}\text { Is essential in the implementation of system or } \\
\text { business models affected by the dynamics of } \\
\text { problems, and takes into account the } \\
\text { environmental, resources, technology, and } \\
\text { consumer demand. }\end{array}$ & $\operatorname{EMF}(2013,2015)$ \\
\hline Enabler 1 & $\begin{array}{l}\text { Technology- } \\
\text { driven }\end{array}$ & $\begin{array}{l}\text { Suitable and economically viable technologies } \\
\text { may be adopted to enable tracing the materials } \\
\text { and products throughout the circulation, } \\
\text { particularly in product recovery. The main goal is } \\
\text { to achieve efficiency and effectiveness that } \\
\text { supports optimisation of operations. }\end{array}$ & $\begin{array}{l}\text { Geng and Doberstein } \\
\text { (2008); Pan et al. (2015) }\end{array}$ \\
\hline Enabler 2 & $\begin{array}{l}\text { Market } \\
\text { availability }\end{array}$ & $\begin{array}{l}\text { Either a new or existing market availability will } \\
\text { enable CE to create new business opportunities, } \\
\text { thus encouraging the reusability of products, } \\
\text { components or materials. }\end{array}$ & $\begin{array}{l}\text { Geng and Doberstein } \\
\text { (2008); Preston (2012); } \\
\text { Stahel (2013); Ma et al. } \\
\text { (2015) }\end{array}$ \\
\hline Enabler 3 & Innovation & $\begin{array}{l}\text { Enables CE by suggesting the use of new, novel } \\
\text { methods and ideas to stimulate redesign and }\end{array}$ & $\begin{array}{l}\text { IMSA (2013); Sempels } \\
\text { (2013) }\end{array}$ \\
\hline
\end{tabular}




\begin{tabular}{|l|l|l|l|}
\hline & $\begin{array}{l}\text { rethink a system in CE to reach the optimum } \\
\text { results of its purpose. }\end{array}$ & \\
\hline
\end{tabular}

Mapping CE values to RRL is the systematic process by which CE principles, attributes and enablers can be evaluated and considered for adoption within reverse logistics processes. For instance, with the principle of cascades orientation embedded into the product take-back scheme, the end-of-life product will not go straight to recycling, but will be cascaded to the next level, i.e. repair or refurbish, and then be reused. The cascading principle therefore aims to increase awareness that there are other opportunities for product recovery than simply recycling.

Attributes are other aspects that one would possibly expect to see within the CE environment, e.g. collaborative networks. In the context of cascades orientation, perhaps companies have horizontal collaboration networks with specialist refurbishers that they may not have had previously.

Finally the enabler, e.g. the availability of secondary markets, allows companies to sell refurbished products at a higher utility. Thus, there must be this enablement that exists to allow the principles to operate alongside the intrinsic attributes.

Embedding or mapping CE values into RRL processes involves the following steps:

1. Decide the product recovery options, e.g. re-sell, repair, refurbish, remanufacture and parts-harvesting, recycling.

2. For each option, identify the reverse logistics processes involved, e.g. transportation, collection, assessment, test, repair, disassemble.

3. Map CE values to the recovery options and relevant processes

While not a central focus of this research, the principles, attributes and enablers may have implications for the existing and future relationships. It is envisaged that during the mapping and interpretation phase, retailers would evaluate their current insourced/outsourced operations and apply CE values to them. In so doing, existing relationships may need to be re-evaluated and lead to a more collaborative or shared vision. Further, we envisage that when retailers evaluate the existing supply chain structures, new outsourcing opportunities may arise to support the move towards a more circular approach. 


\subsection{Performance measurement}

The last element of our framework is performance measurement. While it is beyond the scope of this paper to review, there is a substantive body of research pertaining generally to organisational performance management and measurement in the extant literature (see Neely (2005) for a review and evolution of performance measurement research) while others have begun to consider decision support tools and performance measurement for supply chains (see Akyuz and Erkan, 2010). A number of authors have considered practices that lead to improvements in reverse logistics performance (Daugherty et al., 2001; Richey et al., 2005; Ramirez, 2012; Turrisi et al., 2013; Morgan et al., 2016), but few have actually proposed Performance Measurements Systems (PMSs) or Key Performance Indicators (KPIs) and metrics (see Shaik and Abdul-Kader, 2012). Further, scholars have studied performance in relation to sustainable supply chain management (Grosvold et al., 2014; Schaltegger and Burritt, 2014; Varsei et al., 2014; Santiteerakul et al., 2015). While this substantive body of literature discusses a number of dimensions relating to performance measurement, there is little discourse specifically in consideration of RRL and CE values. We surmise that this is a reflection of the relative immaturity of the subject and, as yet, an unexplored area of research. We therefore hypothesise that performance measurement would be essential to guide the implementation of $\mathrm{CE}$ values and assess its effectiveness.

\section{DISCUSSION}

Existing research in the domain of reverse logistics has previously focused on enhancing competitive advantage (Stock et al., 2006), process management (Kleindorfer et al., 2005), asset recovery values and regulation compliance (Ferguson and Browne, 2001; Toffel, 2003), and re-use/recycling activities (Loomba and Nakashima, 2012). A limited body of research has considered the wider sustainability aspects involved but there is a dearth of knowledge considering $\mathrm{CE}$ adoption within reverse logistics operations. Our framework is timely for two reasons; firstly, a growing recognition that the 'take, make, dispose' approach to business is simply unsustainable and secondly, there is an absence of understanding how to operationalise CE values within businesses.

While frameworks for CE (EMF, 2013; Witjes and Lozano, 2016; Ghisellini et al., 2016) and reverse logistics (Rogers et al., 2002; Bernon et al., 2011; Chan et al., 2012) exist, and a number of authors have sought to establish links between reverse logistics and sustainability and closed 
loop systems (e.g. Turrisi et al., 2013; Govindan et al., 2015), we postulate that we are among the first to present a framework that combines the two phenomena of CE and RRL.

In our thought process, we originally postulated that the success of $\mathrm{CE}$ embeddedness in reverse logistics would be a function of the ease with which CE values could simply be incorporated and applied within existing reverse logistics processes. However, the framework draws on the literature by recognising that embedding $\mathrm{CE}$ would necessitate organisations to take a broader and more holistic approach, reflecting the importance of the 'tone from the top' and the 'managerial implications'. Further, the literature and empirical results combined then consider a range of antecedents necessary to facilitate this process. These are important considerations as stated by Interviewee P:

"For this to work, it's got to be not only easy for the company, it's got to be easy and explicable to the consumer." (Interviewee $\mathrm{P}$ )

The detailed empirical findings will be discussed in the following sections. The discussion is grouped according to the elements of our framework.

\section{1 'Tone from the top'}

\section{a. Vision and leadership}

Our empirical findings are in alignment with the literature when considering similar sustainability and environmental programmes where the 'tone from the top' was seen as important. Without this, any CE initiative would be limited as the reverse logistics function alone would not have the power or influence to bring about the necessary changes. CE was seen as needing cross-functional support. This view was exemplified by Interviewee U, who commented:

"Yes, I think it's like anything, any big policy shift for the business you need top level commitment, and it needs to be very clearly indicated, such that then it can start to drive decision making, and people can then point to it to say well this feeds into that..." (Interviewee U).

Interestingly, while reverse supply chain considerations should be a part of an organisation's corporate strategy (Loomba and Nakashima, 2012), it became evident that most of our interviewees considered CE could be an area for potential conflict, with implications for the 
existing business model, and the cross-functional nature and scale would necessitate senior management leadership.

"...It needs a commitment because there will be conflict, despite the whole overarching thing of CE, it does make sense of course, you can't question it, but when you come down to the nitty-gritty detail there are conflicts all over the place... conflicts between functions." (Interviewee U).

Moreover, our empirical evidence supports the view that senior management commitment needs vision that communicates the desired goals and creates the level of organisational engagement and commitment to drive towards a more circular approach.

“...you do need almost an organisational vision. Well I suppose in my case, around returns and returns management and what it is you're trying to achieve..." (Interviewee $\mathrm{N})$.

While senior management leadership and vision may be a rather overstated point within any business initiative, this recurring theme was felt to be important in providing the direction and motivation to influence the managers involved, and concurs with documented cases of $\mathrm{CE}$ adoption where it is evident that senior management vision has been important.

Whereas reverse logistics management has been considered a rather stand-alone function, our observations suggest that a systems view needs to be taken. This is supported by one of the key values of $\mathrm{CE}$ (i.e. circularity) where a more collaborative and integrative perspective needs be taken on CE solutions.

\section{b. Competitive positioning and commercial considerations}

A further antecedent supported by our empirical data was the alignment of CE values with the competitive positioning and commercial aspects of the business. This was unanimously expressed by interviewees. A number of interviewees could see the benefits of adopting a $\mathrm{CE}$ approach for the benefit of society but this needed to align with the commercial realities of the business. To embark on CE, the competitive positioning and commercial considerations needed to be considered and this could be a barrier to $\mathrm{CE}$ adoption. In particular, Interviewee $\mathrm{P}$ commented that, 
“...because it's good in its own right, it needs somehow to find its home within a commercial structure, which may challenge the commercial structure to change the way it charges." (Interviewee P).

Though CE clearly promotes regenerative and restorative materials via differing routes of product recovery, Interviewee $\mathrm{O}$ especially emphasised the importance of commercial implications before deciding the recovery options.

“...there's a commercial box saying sort your commerciality out before you start making choices [recovery choices] ... otherwise, the choices end up being made in isolation..." (Interviewee O).

And furthermore, Interviewee $\mathrm{H}$ stated:

"Organisationally you need to be aligned commercially... and the organisation has got to have a degree of commitment around this and then you get into [the] selecting your [recovery] options" (Interviewee $\mathrm{H})$.

\subsection{Managerial implications}

\section{a. CSR/Sustainability/Green Agenda}

Interestingly, we found that the majority of the interviewees considered $\mathrm{CE}$ as an extension to their sustainability and/or green agenda and there was consensus that $\mathrm{CE}$ needed to be positioned within their organisations' overall CSR programme. While there are common goals between the concepts of $\mathrm{CE}$ and sustainability, an important consideration is that their guiding principles and modus operandi differ. While we concede that CE needs to be positioned within an organisation's overall CSR framework, we also posit that this response from interviewees was probably because while managers have a 'working' knowledge, the principles of CE are not fully understood by practitioners. This lack of clarity was observed by Interviewee P:

"I think that because it's a crowded area, we talked about CSR, we talked about sustainability, we're talking about the circular economy. Some clearer positioning around where the boundaries are between those I think would be helpful and what the relationship is, because most people entering into this would go, is this just another extension of the old... at the very crudest, is this just another extension of the green agenda?" (Interviewee P). 


\section{b. Product portfolio}

Another managerial implication discussed by our interviewees was the alignment between $\mathrm{RRL} / \mathrm{CE}$ and the product portfolio, product design and selection of materials. These factors not only affect the recovery options that can be applied during the reverse logistics phase, but more importantly, can be the determinant of the durability of the product, which intrinsically supports the CE principle of retained value. In this respect, companies aiming to pursue RRL/CE need to have procedures that feedback information from the returns process to the design process, as described by Interviewee U:

"We have massive influence on a large number of the factories we use, because we are one of their biggest customers, so if we can actually initiate, based on legislation, a change to a component, whether it be a material or whatever, or a design ... there are big commercial stakes meaning that you've got the leverage then to influence more." (Interviewee U).

Design has been identified as a critical starting point in reverse logistics, especially when alignment to $\mathrm{CE}$ is taken into account. Product design should therefore be considered much earlier in the process, even before considering the recovery options. This was emphasised by Interviewee $\mathrm{S}$ during the interview:

"So the way it's written at the moment, we had reverse logistics, do you start here, which was basically stage one on this one, or do you actually start at product design? So I just thought this is missing..." (Interviewee S).

\section{c. Supply chain integration}

The need for an interdisciplinary approach to reverse logistics has been reported by other researchers. Cullen et al. (2013) suggested a range of inter-firm actors including Store operations, Finance, Trading and Logistics when managing the total cost of product return in a retail context, while Bernon et al. (2013) considered a number of dimensions to inter-firm integration between consumers, retailers, logistics service providers and contract manufacturers to reduce the number of product returns from consumers. Further, Bernon et al. (2013) described the importance of the seniority and span of control of those responsible for returns management to bring about change. From our empirical results, it was clear that an integrated approach to aligning RRL and CE was needed. Further work is needed to consider these linkages between functions and how this would be integrated within existing reverse 
logistics processes along with the span of control of the reverse logistics manager, as stated by Interviewee P:

"...where does the stuff all sit within the organisation and tie into organisational design? So it's all very good having this framework but if it's misaligned to organisational responsibilities and incentives, it's going to be an interesting dashboard that gets sent around once a month and quietly binned." (Interviewee P).

This was further elaborated upon by Interviewee $U$, especially when asked to comment on its potential applicability:

“...it can be applied, but it's the same as anything like this, why it's difficult is not because of the concept, it's because it's very, very cross-functional. There are stakeholders all over this, and often the challenge is getting everybody's objectives aligned..." (Interviewee U).

We support this view and further posit that reverse logistics managers need to be empowered to positively interact and influence functions across their own business along with their trading partners, with regard to $\mathrm{CE}$.

While the literature acknowledges the significance of inter-firm integration, this issue did not feature in our interview data. We postulate that this may be because most CE implementations are yet to fully mature, and therefore companies are embarking on internal integration first before proceeding to inter-firm integration. This is in line with Stevens (1989) who stated that there is a hierarchy to supply chain integration namely, base line, functional, internal and external integration.

\section{d. Compliance regulation}

While there was limited discussion pertaining to regulation, there was some acceptance that there was likely to be increasing statutory obligations placed on organisations in the future to extend existing producer responsibility legislation and waste management regulations. In this regard, we have retained this element purely as a mechanism to manage risk and ensure compliance with legal requirements.

\section{e. Customer-centricity}

While customer-centricity was not discussed by interviewees, those who mentioned it thought it was a significant issue as organisations were increasingly focusing on this aspect. The 
implications were twofold, one that the customer was considered within any CE initiative with little impact on their shopping experience and the other relating to the quality of products, in that returns relating to quality should be avoided in the first place, as noted by Interviewees $\mathrm{P}$ and $\mathrm{N}$ :

"I guess the point where they're moving on to now is customer-centric... something that should be built around a concept that says make it as consumer friendly..." (Interviewee $\mathrm{P})$.

“...we're looking at minimising our levels of loss across the business on returns, and also maximising the customer satisfaction with their experience..." (Interviewee N).

\section{f. Collaboration}

Evidence from literature suggests that new collaborative models need to emerge to facilitate the cascading and circularity of returned products. However, there was only limited recognition of this from our interviewees. We postulate that this may be because only when organisations embark on CE initiatives, do they then recognise that their existing networks require additional capabilities. We also suggest, as stated above, that the lack of clarity of the principles of CE means that reverse logistics managers do not yet fully appreciate the full nature of CE. From our results there does appear to be a lack of understanding of collaborative relationships needed to fulfil a CE initiative.

\subsection{Embedding CE values in RRL processes}

The final element of the framework was the mapping and interpretation of CE values directly to RRL processes. While interviewees could comprehend the overall direction of the CE values, it was not always evident to them how they could be applied in practice. Some principles needed interpretation, for example, the concept of 'leakage', while other principles are more conceptual in nature, making interpretation within reverse logistics more problematic and open to misinterpretation, e.g. the principle of 'cascading' suggests that organisations need to keep material longer in circulation or to keep products at their highest utility. This was often confused by our interviewees who believed that they were circular because their products were becoming more recyclable and demonstrated a lack of awareness of real concepts associated with CE values, in this case the cascading of products to retain products at their highest utility where in fact recycling is considered the lowest order of cascading. 
In conclusion, while our interviewees understood the process of mapping the CE principles to RRL processes, it is evident that a key enabler would be the level of understanding returns managers had of the principles. Further, we found issues with the semantics, whereby the terms used in RRL and CE do not align directly. Interestingly, we found evidence of where reverse logistics practices were aligned with CE principles but had not been recognised as such by organisations. As an example, one of the interviewees who sold car accessories and bicycles, stated that they were using 'avoidance techniques', which is a common method used in reverse logistics, to reduce the levels of unnecessary returned goods by customers (Stock et al., 2006). Some of these techniques included sophisticated initiatives, for example, a service known as 'We-Fit' where for a small charge store staff fit car accessories and replacement parts on to the car to avoid customers facing problems with fitting them themselves and returning the products to store. They also offered a bicycle repair and maintenance service to customers along with the stocking of spare parts. All three of these services are considered to exhibit aspects of the CE values described in Table 1, most notably, Principles 1 and 4, Attribute 2, Enablers 2 and 3.

We therefore concede that while our framework suggests a mechanism by which practitioners can map and interpret $\mathrm{CE}$ values against their reverse logistics processes, we recognise that this is an area worthy of further development and refinement. We also envisage that the process would take time as stated by one interviewee:

"It doesn't mean that suddenly a returns manager comes in and just saves the whole business..., but it's lots of chipping away at trying to understand the reasons why you're incurring the loss and then prioritising actions accordingly." (Interviewee N).

\subsection{Performance measurement}

While the extant literature offers a number of lenses through which to consider performance measurement at an organisational level, and supply chain and sustainability dimensions, it is almost silent in offering appropriate measures, KPIs or PMS that support the evaluation of performance from linear to circular models. One of the few is provided by Tuppen (2016) which contrasts traditional sustainability performance criteria with those of CE. While it offers some guidance on the nature of performance measurement and illustrative metrics, further research is needed to develop and test PMS for CE in returns systems. This was supported in our empirics, in that interviewees recognised the importance of performance measurement but none could offer any experience of their use. 


\section{CONCLUDING COMMENTS}

This study presents a framework that supports the adoption of CE values within RRL. In so doing, we combined the extant literature with rich empirical data. We found that, while there is increasing evidence for the need to move towards a $\mathrm{CE}$, there has been little discourse in the academic literature offering support for practitioners to embed CE values within RRL operations. Moreover, there is limited understanding of the antecedents for successful adoption. The results presented in this paper extend our knowledge both in reverse logistics and CE literature.

We are amongst the first who argue that the discourse in academic literature linking RRL practice with $\mathrm{CE}$ has been lacking, and we recognise that this is due to limited understanding of the managerial implications and antecedents. Our empirical research reported in this paper has contributed to these antecedents and, as our understanding of the linkage between CE and reverse logistics improves, we will be able to contribute more to this vital area of research.

While we recognise the methodological limitations associated with qualitative data and sample size, the development of the conceptual framework derives from an iterative process between extant literature on reverse logistics and exploratory interviews with senior managers with significant managerial experience of reverse logistics operations. This joining of theory and practice has therefore provided rich empirical results, made a contribution to the broader reverse logistics field, and bridged the gap that exists in our understanding of the management of reverse logistics flows in consideration of $\mathrm{CE}$ values.

A framework, by definition, explains the constructs, factors, variables, and the relationships amongst them (Miles et al., 2014). Although exploratory in nature, our framework offers a starting point for practitioners to consider the building blocks necessary to implement and embed CE principles in RRL. More generally, through the dissemination of our framework, we provide insights to a practitioner audience of the antecedents that enable CE values in RRL operations. Further, through the mapping and interpretation elements of the framework, practitioners have a mechanism by which they can embed CE values in their RRL processes.

For our academic colleagues, we have provided a conceptual framework which highlights significant opportunities for future research. While this paper identifies a number of antecedents, there is a need for a deeper investigation into the barriers and facilitators relating to CE adoption in RRL. Further, investigation is required to explore the role for intra- and inter- 
supply chain integration and emerging models of organisational collaboration. With regard to embedding CE values within RRL processes, further work is needed to understand how CE values can be more readily interpreted within the operations of reverse logistics.

Conversely, research could support methods by which organisations could identify the opportunities for identifying CE good practice. Research is needed to explore performance measurement systems in support of CE reverse logistics processes that, in turn, support and encourage the correct behaviours leading to enhanced performance. Finally, a possible limitation is that the research focuses on large retailers and further work is required to assess the generalisability of the framework with small to medium-sized organisations.

\section{REFERENCES}

Akyuz, A. G. and Erkan, E. T., 2010. "Supply chain performance measurement: a literature review." International Journal of Production Research, 48 (17): 5137-5155.

Ameli, M., S. Mansour, and A. Ahmadi-Javid. 2016. "A multi-objective model for selecting design alternatives and end-of-life options under uncertainty: A sustainable approach." Resources, Conservation and Recycling 109: 123-136.

Barratt, M., T. Y. Choi, and M. Li. 2011. "Qualitative case studies in operations management: Trends, research outcomes, and future research implications." Journal of Operations Management, 29 (4): 329-342.

Bernon, M., and J. Cullen. 2007. "An integrated approach to managing reverse logistics". International Journal of Logistics: Research and Applications 10 (1): 41-56.

Bernon, M., J. Upperton., M. Bastl, and J. Cullen. 2013. “An exploration of supply chain integration in the retail product returns process." International Journal of Physical Distribution \& Logistics Management 43 (7): 586-608.

Bernon, M., J. Cullen, and J. Gorst. 2016. "Online retail returns management: Integration within an omni-channel distribution context." International Journal of Physical Distribution \& Logistics Management 46 (6/7): 584-605.

Bernon, M., S. Rossi, and J. Cullen. 2011. "Retail reverse logistics: A call and grounding framework for research." International Journal of Physical Distribution and Logistics Management 41 (5): 484-510.

Blackburn, J. D., V. D. R. Guide, Jr., G. C. Souza, and L. N. Van Wassenhove. 2004. "Reverse supply chains for commercial returns.” California Management Review 46 (2): 6-22.

Bostel, N., P. Dejax, and Z. Lu. 2005. "The design, planning, and optimization of reverse logistics network." In Logistics systems: Design and optimization, edited by A. Langevin., and D. Riopel. Springer.

Carter, C., and L. Ellram. 1998. "Reverse Logistics: A Review of the Literature and Framework for Future Investigation.” Journal of Business Logistics 19 (1): 85-102.

Chan, T. S., H. K. Chan, and V. Jain. 2012. "A framework of reverse logistics for the automobile industry." International Journal of Production Research 50 (5): 1318-1331. 
Chen, J. 2009. "Material Flow and Circular Economy Systems." Systems Research and Behavioral Science 26: 269-278.

Creswell, J.W., 2013. Research design: Qualitative, quantitative, and mixed methods approaches. Sage publications.

Cullen, J., M. Tsamenyi., M. Bernon, and J. K. Gorst. 2013. "Reverse logistics in the UK retail sector: a case study of the role of management accounting in driving organisational change." Management Accounting Research 24 (3): 212-227.

Dajian, Z. 2008. "Background, pattern and policy of China for developing circular economy." Journal of Population, Resources and Environment 6 (4): 3-8.

Daugherty, P. J., C. W. Autry, and A. E. Ellinger. 2001. "Reverse logistics: The relationship between resource commitment and program performance." Journal of Business Logistics 22 (1): 107-124.

Daugherty, P. J., R. G. Richey., S. E. Genchev, and H. Chen. 2005. "Reverse logistics: superior performance through focused resource commitments to information technology." Transportation Research 41 (2): 77-92.

Dhakal, M., M. H. Smith, and R. Newbery. 2016. "Secondary Market: A Significant Aspect in Reverse Logistics and Sustainability." International Journal of Social Sustainability in Economic, Social and Cultural Context, 12 (1): 24-35.

Du, S., C. B. Bhattacharya, and S. Sen. 2007. "Reaping relational rewards from corporate social responsibility: The role of competitive positioning." International Journal of Research in Marketing, 24: 224-241.

Du, F., and G. W. Evans. 2008. "A bi-objective reverse logistics network analysis for post-sale service." International Journal of Computers and Operations Research 34: 1-18.

Dubé, L., and G. Paré, G. 2003. "Rigor in information systems positivist case research: current practices, trends and recommendations." MIS Quarterly 27 (4): 597-635.

Eisenhardt, K. M. 1989. "Building theories from case study research." Academy of Management Review 14 (4): 532-550.

Elkington, J. 1997. Cannibals with Forks: The Triple Bottom Line of 21st Century Business. Capstone.

EMF (Ellen MacArthur Foundation). 2013. "Towards the Circular Economy 1: Economic and business rasionale for an accelerated transition." Ellen MacArthur Foundation. Accessed Nov. 02 2013. http://www.ellenmacarthurfoundation.org/business/reports/ce2012.

EMF (Ellen MacArthur Foundation). 2015. "Circular economy overview." Ellen MacArthur Foundation. Accessed Dec. 06 2015. http://www.ellenmacarthurfoundation.org/circulareconomy/overview/principles.

European Commission. 2015. "Communication from the commission to the European Parliament, the Council, the European Economic and Social Committee and the Committee of the Regions: Closing the loop - An EU action plan for the Circular Economy." Accessed Oct. $02 \quad 2016 . \quad$ http://eur-lex.europa.eu/legalcontent/EN/TXT/?uri=CELEX:52015DC0614,.

European Commission. 2016. "Review of Waste Policy and Legislation." Accessed Oct. 02 2016. http://ec.europa.eu/environment/waste/target_review.htm. 
European Environment Agency. 2016. Accessed Feb. $02 \quad 2017$ http://www.eea.europa.eu/highlights/circular-economy-to-have-considerable ()

European Union. 2015. Closing the loop - An EU action plan for the Circular Economy, http://eur-lex.europa.eu/legal-content/EN/TXT/?uri=CELEX:52015DC0614 (accessed 2 Feb 2017)

Ferguson, N., and J. Browne. 2001. "Issues in end-of-life product recovery and reverse logistics.” Production Planning \& Control 12 (5): 534-547.

Fleischmann, M. 2001. Reverse Logistics Network Structure and Design. Rotterdam: Erasmus Research Institute of Management (ERIM).

Flynn, B.B. , Huo, B. and Zhao, X. (2010), "The impact of supply chain integration on performance: a contingency and configuration approach", Journal of Operations Management, Vol. 28, pp. 58-71.

Geng, Y., and B. Doberstein. 2008. "Developing the circular economy in China: challenges and opportunities for achieving 'leapfrog development'." International Journal of Sustainable Development \& World Ecology 15: 231-239.

Geng, Y., J. Fu., J. Sarkis, and B. Xue. 2012. "Towards a national circular economy indicator system in China: an evaluationand critical analysis." Journal of Cleaner Production 23: 216-224.

Geng, Y., Q. Zhu., B. Doberstein, and T. Fujita. 2009. "Implementing China's Circular Economy Concept at the Regional Level: A review of Progress in Dalian, China." Waste Management 29: 996-1002.

Genovese, A., A. A. Acquaye, A. Figueroa, and S. L. Koh. 2017. "Sustainable supply chain management and the transition towards a circular economy: Evidence and some applications." Omega, 66: 344-357

Ghisellini, P., C. Cialani., and S. Ulgiati. 2016. "A review on circular economy: the expected transition to a balanced interplay of environmental and economic systems." Journal of Cleaner Production 114: 11-32.

Govindan, K., H. Soleimani, and D. Kannan. 2015. "Reverse logistics and closed-loop supply chain: A comprehensive review to explore the future." European Journal of Operational Research 240 (3): 603-626.

Govindan, K., M. Palaniappan., Q. Zhu, and D. Kannan. 2012. "Analysis of third party reverse logistics provider using interpretive structural modelling." International Journal of Production Economics 140 (1): 204-211.

Grayson, D. 2011. "Embedding corporate responsibility and sustainability: Marks \& Spencer." Journal of Management Development 30 (10): 1017-1026.

GRI 2015. G4 Sustainability Reporting Guidelines. (accessed Feb. 24 2017) https://www.globalreporting.org/resourcelibrary/GRIG4-Part1-Reporting-Principlesand-Standard-Disclosures.pdf

Grosvold, J., S. Hoejmose, and J. Roehrich. 2014. "Squaring the circle: Management, measurement and performance of sustainability in supply chains." Supply Chain Management: An International Journal 19 (3): 292-305.

Hongchun, Z. 2006. "Circular economy in China and recommendations." Ecological Economy 2: $102-114$. 
Hooley, G., A. Broderick, and K. Möller. 1998. "Competitive positioning and the resourcebased view of the firm." Journal of Strategic Marketing, 6: 97-115.

Horvath, P. A., C. W. Autry, and W. E. Wilcox. 2005. "Liquidity implications of reverse logistics for retailers." Journal of Retailing 81 (3): 191-205.

Hu, J., Z. Xiao., R. Zhou., W. Deng., M. Wang, and S. Ma. 2011. "Ecological utilization of leather tannery waste with circular economy model." Journal of Cleaner Production 9: 221-228.

Huamao, X., and W. Fengqi. 2007. "Circular economy development mode based on system theory." Chinese Journal of Population Resources and Environment 5 (4), 92-96.

IMSA. 2013. Unleashing the Power of the Circular Economy. Amsterdam: IMSA.

Kleindorfer, P. R., K. Singhal, and L. N Van Wassenhove, L.N. 2005. "Sustainable Operations Management." Production and Operations Management 14 (4): 482-492.

Kopicki, R. J., M. J. Berg., L. Legg., V. Dasappa, and C. Maggioni. 1993. Reuse and Recycling: Reverse Logistics Opportunities. Oak Brook: Council of Logistics Management.

Lacy, P., and J. Rutqvist. 2015. Waste to wealth: the circular economy advantage. New York: Palgrave Macmillan.

Lambert, D. M., and J. R. Stock. 1987. Strategic Physical Distribution Management. Homewood, IL: Irwin.

Lambert, S., D. Riopel, and W. Abdul-Kader. 2011. "A reverse logistics decisions conceptual framework." Computers \& Industrial Engineering 61 (3): 561-581.

Li, W., W. Shen, and W. Chen. 2009. "Research on Key Technologies of Knowledge-Based Engineering Decision Support System for Circular Economy". Second Asia-Pacific Conference on Computational Intelligence and Industrial Applications.

Loomba, P. S., and K. Nakashima. 2012. "Enhancing value in reverse supply chains by sorting before product recovery." Production Planning \& Control 23 (2-3): 205-215.

Lu, Z., and N. Bostel. 2007. "A facility location model for logistics systems including reverse flows: The case of remanufacturing activities." Computers \& Operations Research 34 (2): 299-323.

Ma, S., S. Hu., D. Chen, and B. Zue. 2015. "A case study of a phosphorus chemical firm's application of resource efficiency and eco-efficiency in industrial metabolism under circular economy." Journal of Cleaner Production 87: 839-849.

Malhotra, A., N. P. Melville, and R. T. Watson. 2013. "Spurring impactful research on information systems for environmental sustainability." MIS Quarterly, 37 (4): 12651274.

Mason, S. 2002. "Backward progress.” IIE Solutions 34: 42-6.

Mathews, J. A., and H. Tan. 2011. "Progress toward a circular economy in China: the drivers (and inhibitors) of eco-industrial initiative." Journal of Industrial Ecology 15 (3): 435457.

McCutcheon, D.M., Meredith, J.R., 1993. "Conducting case study research in operations management." Journal of Operations Management 11 (3), 239-256. 
Meade L., and J. Sarkis. 2002. "A conceptual model for selecting and evaluating third-party reverse logistics providers." Supply Chain Management: An International Journal 7 (5): 283-295.

Meier, H., Roy, R. and Seliger, G., 2010. Industrial product-service systems-IPS 2. CIRP Annals-Manufacturing Technology, 59(2), pp.607-627.

Miles, M. B., A. M. Huberman, and J. Saldaña. 2014. Qualitative Data Analysis, 3rd Edition. Thousand Oaks, CA: Sage.

Morgan, T. R., R. G. Richey, Jr, and C. W. Autry. 2016. "Developing a reverse logistics competency." International Journal of Physical Distribution \& Logistics Management 46 (3): 293-315.

Murphy, P. R. 1986. "A Preliminary Study of Transportation and Warehousing Aspects of Reverse Distribution." Transportation Journal 35 (4): 12-21.

Murphy, P., and R. Poist. 1989. "Management of Logistical Retromovements: An Empirical Analysis of Literature Suggestions." Transportation Research Forum 291: 177-184.

Mutha, A., and S. Pokharel. 2009. "Strategic network design for reverse logistics and remanufacturing using new and old product modules." Computers \& Industrial Engineering 56: 334-346.

Neely, A. 2005. "The evolution of performance measurement research: Developments in the last decade and a research agenda for the next." International Journal of Operations \& Production Management 25 (12): 1264-1277.

Neto, J. Q. F., J. Bloemhof, and C. Corbett. 2016. "Market prices of remanufactured, used and new items: Evidence from eBay." International Journal of Production Economics, 171: 371-380.

Pan, S., M. A. Du., I. Huang, I. Liu., E. Chang, and P. Chiang. 2015. "Strategies on implementation of waste-to-energy (WTE) supply chain for circular economy system: a review." Journal of Cleaner Production 108: 409-421.

Park, J., J. Sarkis, and Z. Wu. 2010. Creating integrated business and environmental value within the context of China's circular economy and ecological modernization, Journal of Cleaner Production, 18 (15): 1494-1501.

Pinjing, H., L. Fan., Z. Hua, and S. Liming. 2013. "Recent Developments in the Area of Waste as a Resource, with Particular Reference to the Circular Economy as a Guiding Principle." In Waste as a Resource, edited by R. Hester, and R. Harrison, Vol. Environmental Science and Technology. The Royal Society of Chemistry.

Pintér, L. 2006. Circular Economy in China: Moving from Rhetoric to Implementation. The Environment and Social Development Sector Unit, East Asia and Pacific Region. The World Bank.

Pishvaee, M., F. Jolai, and J. Razmi. 2009. "A stochastic optimization model for integrated forward/reverse logistics network design.” Journal of Manufacturing Systems 28: 107114.

Prahinski, C., and C. Kocabasoglu. 2006. "Empirical research opportunities in reverse supply chains." The International Journal of Management Science 34: 519-532.

Preston, F. 2012. "A Global Redesign? Shaping the circular economy”. Chatham House. Accessed 
http://www.chathamhouse.org/sites/files/chathamhouse/public/Research/Energy,\%20En vironment\%20and\%20Development/bp0312_preston.pdf.

Ramírez, A. M. 2012. "Product return and logistics knowledge: Influence on performance of the firm. Transportation Research. Part E." Logistics \& Transportation Review 48 (6): $1137-1151$.

Ravi, V., and R. Shankar. 2005. "Analysis of interactions among the barriers of reverse logistics.” Technological Forecasting and Social Change 72 (8): 1011-1029.

Richey, R.G., S. E. Genchev, and P. J. Daugherty. 2005. "The role of resource commitment and innovation in reverse logistics performance." International Journal of Physical Distribution \& Logistics Management 35 (3): 233-257.

Ripanti, E. 2017. A Method to Design Reverse Logistics Operations based on Circular Economy Values, $\mathrm{PhD}$ Thesis, Cranfield University

Rogers, D., and R. S. Tibben-Lembke. 1999. Going Backwards: Reverse Logistics Trends and Practices. Pittsburgh: RLEC Press.

Rogers, D., and R. Tibben-Lembke. 2001. "An examination of reverse logistics practices." Journal of Business Logistics 22 (2): 129-148.

Rogers, D. S., D. M. Lambert., K. L. Croxton, and S. Garcia-Dastugue. 2002. "The returns management process". International Journal of Logistics Management 13 (2): 1-18.

Salema, M., A. P. Barbosa-Povoa, and A. Q. Novais. 2007. "An optimization Model for the Design of a Capacitated Multi-product Reverse Logistics Network with Uncertainty." European Journal of Operational Research 179: 1063-1077.

Santiteerakul, S., A. Sekhari, A. Bouras, and A. Sopadang. 2015. "Sustainability performance measurement framework for supply chain management." International Journal of Product Development 20 (3): 221-238.

Schaltegger, S., and R. Burritt. 2014. Measuring and managing sustainability performance of supply chains: Review and sustainability supply chain management framework. Supply Chain Management: An International Journal 19 (3): 232-241.

Sempels, C. 2013. "Implementing a circular and performance economy through business model innovation." In A New Dynamic Effective Business in a Circular Economy, edited by Webster, K., J. Blériot, and C. Johnson, 144-156. Isle of Wight: Ellen MacArthur Foundation Publishing.

Shaik, M., and W. Abdul-Kader. 2012. "Performance measurement of reverse logistics enterprise: a comprehensive and integrated approach. Measuring Business Excellence 16 (2): $23-34$.

Smith, M. and J. Crotty. 2008. "Environmental regulation and innovation driving ecological design in the UK automotive industry." Business Strategy and the Environment, 17 (6): 341-349.

Srivastava, S. K. 2008. "Network Design for Reverse Logistics." International Journal of Management Science 36: 535-548.

Stock, J. R. 1998. Development and Implementation of Reverse Logistics Programs. Oak Brook, Ill: Council of Logistics Management.

Stock, J. R. 1992. Reverse Logistics, Oak Brook, Ill: Council of Logistics Management. 
Stock, J., T. Speh, and H. Shear. 2006. "Managing Product Returns for Competitive Advantage." MIT Sloan Management Review 48 (1): 57-62.

Stahel, W. R. 2013. "The Business Angle of A Circular Economy: Higher Competitiveness, Higher Resource Security and Material Efficiency." In A New Dynamic Effective Business in a Circular Economy, edited by Webster, K., J. Blériot, and C. Johnson, 4660. Isle of Wight: Ellen MacArthur Foundation Publishing.

Strauss, A., and J. Corbin. 1998. Basics of qualitative research: techniques and procedures for developing grounded theory. Thousand Oaks, CA: Sage Publications.

Stevens, G.C., 1989. Integrating the supply chain. International Journal of Physical Distribution \& Materials Management, 19(8), pp.3-8.

Su, B., A. Heshmati., Y. Geng, and X. Yu. 2013. "A review of the circular economy in China: moving from rhetoric to implementation." Journal of Cleaner Production 42: 215-227.

Sundin, E. and Bras, B., 2005. Making functional sales environmentally and economically beneficial through product remanufacturing. Journal of Cleaner Production, 13(9), pp.913-925.

Tibben-Lembke, R. S., and D. S. Rogers. 2002. "Differences between forward and reverse logistics in a retail environment." Supply Chain Management: An International Journal 7 (5): 271-282.

Thierry, M., M. Salomon., J. V. Nunen, and L. Van Wassenhove. 1995. "Strategic issues in product recovery management." California Management Review 37 (2): 114-135.

Toffel, M. W 2003. “The Growing Strategic Importance of End-of-Life Product Management." California Management Review 45 (3): 102-129.

Tuppen, C. 2016. Circularity Indicators. In: Webster, K., Johnson, C, Blériot, J., Gravis, L. ed. A New Dynamic 2 Effective Systems in a Circular Economy. Isle of Wight: Ellen MacArthur Foundation Publishing, 195-210.

Turrisi, M., M. Bruccoleri, and S. Cannella. 2013. "Impact of reverse logistics on supply chain performance." International Journal of Physical Distribution \& Logistics Management 43 (7): 564-585.

UNEP - United Nations Environment Programme. 2015. www.unep.org. Accessed December 05

2015.

http://www.unep.org/resourceefficiency/Home/Policy/SCPPoliciesandthe10YFP/Natio nalActionPlansPovertyAlleviation/NationalActionPlans/Cir.

Veleva, V., 2008. Product stewardship in the United States: the changing policy landscape and the role of business. Sustainability: Science, Practice, \& Policy, 4 (2).

Varsei, M., C. Soosay, B. Fahimnia, and J. Sarkis. 2014. "Framing sustainability performance of supply chains with multidimensional indicators." Supply Chain Management: An International Journal, 19 (3): 242-257.

Walther, G., and T. Spengler. 2005. "Impact of WEEE-directive on Reverse Logistics in Germany." International Journal of Physical Distribution \& Logistics Management 35 (5): 337-361.

WCED (World Commission on Environment and Development), 1987. Our Common Future. Oxford University Press, Oxford. 
Webster, K. 2015. The circular economy: a wealth of flows. Isle of Wight: Ellen MacArthur Foundation Publishing.

Winkler, H. 2011. "Closed-loop production systems-A sustainable supply chain approach." CIRP Journal of Manufacturing Science and Technology, 4: 243-246.

Witjes, S., and R. Lozano. 2016. "Towards a more Circular Economy: Proposing a framework linking sustainable public procurement and sustainable business models." Resources, Conservation and Recycling 112: 37-44.

Yang, H. 2011. "Research on the construction and management of green supply chain based on circular economy". IEEE Journal.

Yong, R. 2007. "The circular economy in China." Journal of Material Cycles and Waste Management 9 (2): 21-129.

Yuan, Z., J. Bi, and Y. Moriguichi. 2006. "The circular economy: a new development strategy in China." Journal of Industrial Ecology 10 (1-2): 4-8.

Zhu, Q., Y. Geng, and K. Lai. 2010. "Circular Economy Practices among Chinese Manufacturers Varying in Environmental-oriented Supply Chain Cooperation and the Performance Implications.” Journal of Environmental Management 91: 1324-1331. 